\title{
THE FAILURE OF HEPATIC ARTERY LIGATION AND SPLENECTOMY TO INFLUENCE THE COURSE OF A PATIENT WITH ASCITES DUE TO CIRRHOSIS OF THE LIVER
}

In recent years a considerable volume of work has been published on the relationship between portal venous blood-flow and hepatic artery pressure in cases of portal hypertension due to cirrhosis of the liver. As a result of this work, ligation of the hepatic artery has been carried out in the treatment of ascites and oesophageal varices, (Reinhoff, I95I; Berman 195I ; Berman and Hull, 1952; Madden, 1953; Jahnke, Seeley and Palmer, 1953; Desforges, Campbell and Robbins, 1953; McFadzean and Cook, 1953).

The following account is of a case of portal hypertension due to multilobular cirrhosis, treated by ligation of the hepatic artery and splenectomy.

\section{History}

H.B. A married woman of 36 years.

In 1944, this patient experienced a severe attack of jaundice two days after the birth of a still born, full term male child. This jaundice lasted five weeks after which she was in normal health for eight years, and in $195^{\circ}$ was delivered of a live full term female child.

In October 1952, she missed a period and noticed slow increase in abdominal girth, associated with a feeling of lassitude. Two months later a normal period occurred, but her abdomen continued to swell and ankle oedema appeared.

In January 1953 she vomited a small quantity of yellowish fluid which was streaked with bright red blood, and at this time complained of a sensation of obstruction low down in the throat.

During February and March 1953 her abdomen became increasingly distended and she began to complain of breathlessness. In consequence she was admitted to Kettering Hospital and then Westminster Hospital for investigation.

There was no history of alcoholism.

\section{On Examination}

An alert, active woman of generous build and a cqurageously happy disposition. Slight con- junctival icterus was present and numerous telangiectases were to be found scattered over the $O$ face and thorax. Ascites was considerable and $\omega_{t}$ both the liver and spleen were palpable three $\omega$ finger breadths below the costal margin. There ज़ was no obvious superficial venous engorgement, but definite pitting ankle oedema. B.P.r2o/80.

\section{Investigations}

Haemoglobin $=109$ per cent.

X-ray of chest-normal.

Barium swallow: 'Small varices in the low third of the oesophagus.'

Liver function tests-see Table I.

\section{Clinical Diagnosis}

Portal hypertension secondary to cirrhosis of the liver, itself a sequel of sub-acute necrosis (? in- $\overrightarrow{\vec{F}}$ fective hepatitis) in 1944 .

\section{Treatment}

In view of the deterioration in her general condition over the preceding months, the incapaci- 3 tating ascites, the radiologically demonstrable oesophageal varices, and the laboratory evidence of 3 impared liver function, it was decided that $\delta$ surgical treatment was indicated.

The recently described procedure of hepatic 0 artery ligation with splenectomy was considered to be more suitable in this case than porto cavalo anastomosis. Ascites was our patient's chief symptom and it is recognized that porto-cavalos anastomosis gives disappointing results in so far as $N$ this symptom is concerned, whereas hepatic N్లు artery ligation has lead to considerable relief of $\sigma$ ascites in a recently reported series of cases (McFadzean and Cook, 1953). Furthermore, the establishment of an Eck fistula is an operation of? greater magnitude. It was felt that there was little to choose between the two procedures in sofar as improvement of hepatic function was con- $\overrightarrow{\mathbb{D}}$ cerned, since it is rarely improved by Eck fistula 


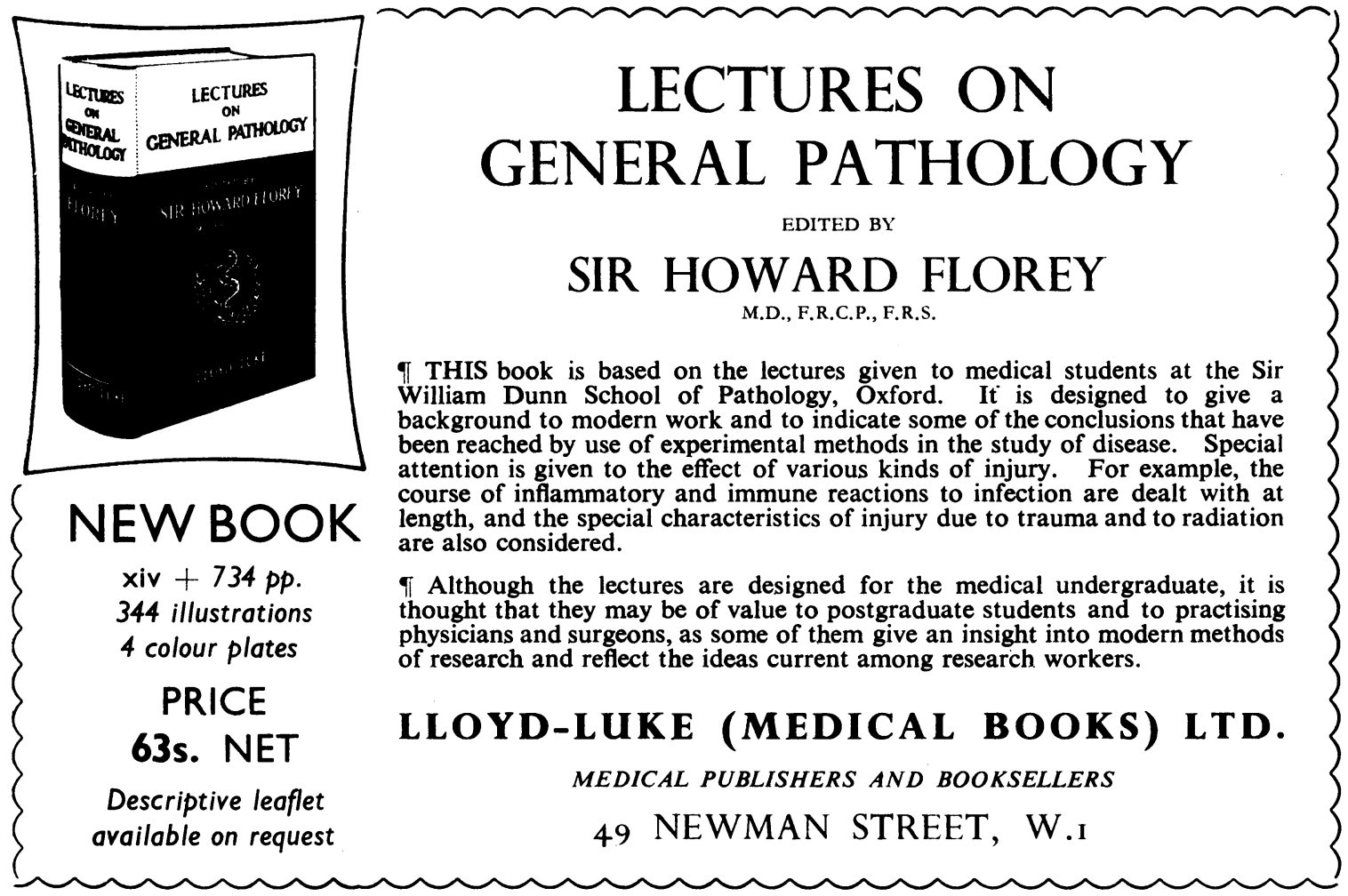

(Palmer et al., 1953) and the literature contains no large series of cases in which the hepatic function has been studied following hepatic artery ligation.

\section{Operation}

Laparotomy under general anaesthetic was performed on April 9. The liver, which was slightly larger than normal, consisted almost entirely of spherical masses $\mathrm{I}$ to $3 \mathrm{~cm}$. in diameter. The spleen was approximately four times larger than normal, smooth and firm. There was a considerable collateral circulation in the lesser omentum and on the inferior aspect of the diaphragm.

The hepatic artery was ligated and divided just distal to the gastro-duodenal branch, and the spleen was removed. A liver nodule was removed for biopsy.

\section{Report on Liver Biopsy}

'The liver shows repair following massive necrosis, large areas of regenerated liver alternating with patches containing bile duct structures in great profusion.... Multiple Nodular Hyperplasia.'

\section{Post-operative Course}

A course of penicillin (500,000 units b.d.) and Streptomycin ( $1.0 \mathrm{~g}$. daily) was begun on the last pre-operative day and the patient was allowed a normal salt intake. Her general condition and progress was satisfactory during the first few postoperative days, but within three days there was clinically detectable ascites, which began to drain freely through the centre of the incision. The loss of electrolytes in the ascitic fluid was replaced by intravenous infusions of normal saline and a liberal salt intake by mouth was given. In spite of this the plasma chlorides and serum sodium levels remained low for a month. At this time, May 18 , I953, the patient's condition had deteriorated, the ascitic fluid loss continued and she was at times drowsy and difficult to rouse. Her alkali reserve was 14.5 m.eq./litre and an attempt was made to correct this by intravenous infusion of onesixth Molar Sodium Lactate. Two days later the patient was much improved and ascitic fluid ceased draining from her incision; however, this clinical improvement preceded the correction of the acidosis by several days. Ascites collected again fairly rapidly and by May 30 , paracentesis was necessary, I $1 \frac{1}{2}$ pints being drained off.

Following operation laboratory tests of the liver function had shown a slow improvement, but during the early half of June her ascites rapidly reformed and she was tapped again on June II, and a further $10 \frac{1}{2}$ pints of ascitic fluid obtained. 
Flocculation Tests

\begin{tabular}{|c|c|c|c|c|c|c|c|c|c|c|c|c|c|}
\hline Date & $\begin{array}{c}\text { Serum } \\
\text { Pro- } \\
\text { tein } \\
\text { Mg. } \\
\% \%\end{array}$ & $\begin{array}{l}\text { Serum } \\
\text { Direct } \\
\underset{\%}{\text { Mg. }}\end{array}$ & $\mid \begin{array}{c}\text { Bilirubin } \\
\substack{\text { Indirect } \\
\text { \%g. }}\end{array}$ & $\begin{array}{l}\text { Serum } \\
\text { Amino- } \\
\text { acid } \\
\mathbf{M g} . \\
\%\end{array}$ & $\begin{array}{c}\text { Serum } \\
\text { Alkaline } \\
\text { Phos- } \\
\text { phatase }\end{array}$ & $\begin{array}{l}\text { Zinc } \\
\text { Sul- } \\
\text { phate }\end{array}$ & Thymol & $\begin{array}{l}\text { Serum } \\
\text { Col- } \\
\text { loidal } \\
\text { Gold }\end{array}$ & $\begin{array}{c}\text { Thymol } \\
\text { Tur- } \\
\text { bidity }\end{array}$ & $\begin{array}{l}\text { Serum } \\
\text { Sodium } \\
\text { m.eq./1. }\end{array}$ & $\begin{array}{c}\text { Serum } \\
\text { Potas- } \\
\text { sium } \\
\text { m.eq. } 1 .\end{array}$ & $\begin{array}{c}\text { Plasma } \\
\text { Chlor- } \\
\text { ides } \\
\text { m.eq./l. }\end{array}$ & $\begin{array}{c}\text { Haemo- } \\
\text { globin }\end{array}$ \\
\hline $29 \cdot 3 \cdot 53$ & 6.0 & Total $=$ & 2.0 & - & 18.7 & - & - & - & 12 & - & - & - & $109^{\circ}$ \\
\hline 2.4 .53 & - & I. 3 & 0.1 & - & 12.0 & 20 & $4^{+}$ & 5 & 20 & - & - & - & $85^{\prime \prime}$ \\
\hline 8.4 .53 & 7.2 & - & - & - & - & 30 & $4+$ & $5-$ & 30 & - & - & - & - \\
\hline $9 \cdot 4 \cdot 53$ & & & & Hepa & tic Artery & $\begin{array}{l}\text { Pivided } \\
\text { erform }\end{array}$ & d Splenec & tomy & & & & & \\
\hline 10.4 .53 & - & 0.5 & 0.7 & 10 & 13.0 & 18 & $4+$ & $5-$ & I 6 & - & - & - & - \\
\hline $13 \cdot 4 \cdot 53$ & - & I.O & 0.6 & 6.5 & 12.0 & 20 & $4+$ & $3+$ & 13 & 125 & 4.2 & - & - \\
\hline $15 \cdot 4 \cdot 53$ & - & I . 4 & 0.9 & 4.8 & - & - & - & - & - & 133 & $4 \cdot 1$ & 95 & - \\
\hline $20.4 \cdot 53$ & $5 \cdot 7$ & I. I & 0.9 & $5 \cdot 5$ & - & 10 & $3+$ & $5+$ & 9 & 114 & $4 \cdot 7$ & 85 & - \\
\hline $24 \cdot 4 \cdot 53$ & - & I. 5 & 1.2 & - & - & 14 & $3+$ & $5+$ & 9 & 126 & 6.0 & - & - \\
\hline $28.4 \cdot 53$ & - & - & - & - & - & - & - & - & - & 126 & 6.5 & 96 & - \\
\hline I. $5 \cdot 53$ & $6 . \mathrm{I}$ & I. 3 & 1.0 & - & - & 10 & $2+$ & $4+$ & 7 & 117 & 5.0 & 90 & $94^{\circ} \mathrm{o}$ \\
\hline 18.5 .53 & - & 1.0 & I. 4 & 7.6 & 18.0 & 15 & $3+$ & $5+$ & 8 & 132 & 6.2 & 110 & - \\
\hline $19.5 \cdot 53$ & - & - & - & - & - & - & - & - & - & 126 & 5.1 & 105 & - \\
\hline $20 \cdot 5 \cdot 53$ & - & - & - & - & - & - & - & - & - & 127 & $4 \cdot 7$ & 100 & - \\
\hline $23 \cdot 5 \cdot 53$ & - & - & - & - & - & - & - & - & - & 120 & $4 \cdot 4$ & 100 & - \\
\hline $26.5 \cdot 53$ & - & - & - & - & - & 16 & $3+$ & $5 !$ & 8 & 119 & $3 \cdot 5$ & 95 & - \\
\hline 4.6 .53 & - & 1.0 & I. I & - & - & 14 & $3+$ & $5+$ & 8 & 132 & $3 \cdot 9$ & 93 & - \\
\hline 8.6 .53 & - & 1.0 & I. I & 5.8 & - & - & - & - & - & 122 & 3.8 & 96 & - \\
\hline 15.6 .53 & - & 1.0 & 1.4 & $4 \cdot 5$ & 17.0 & Io & $3+$ & $5+$ & 8 & 133 & $3 \cdot 1$ & 90 & $-\frac{0}{2}$ \\
\hline $23 \cdot 6 \cdot 53$ & - & 2.0 & 0.1 & 9.3 & 11.0 & 10 & $2+$ & $5+$ & 7 & 121 & 4.7 & 00 & $-\leq$ \\
\hline
\end{tabular}

Table 1.-Biochemical Findings Before and After Operation.

Thereafter her condition rapidly deteriorated, her level of consciousness varying from normal to semi-coma. A barium swallow on June I8 showed marked increase of her oesophageal varices. The patient remained in coma for two days prior to her death on June 23, 1953.

\section{Post-mortem Examination}

The abdomen contained five or six pints of greenish turbid free fluid. The liver was grossly abnormal. As a whole it was shrunken and coarsely nodular, particularly affecting the right lobe, which is about a third of the normal volume. It was unusually pale in colour and broad areas of the surface were flat and smooth indicating complete necrosis at some previous date. Elsewhere large nodules of regenerated liver tissue project above the liver surface. The biliary passages were patent. The portal vein was completely occluded at the level of the portal fissure by ante-mortem clot not more than one week old. The hepatic artery had been ligated half-inch beyond the gastro-duodenal branch.

Histology of the Liver: The appearances are much the same as in the biopsy, apart from low-grade peritonitis causing a purulent exudate on the capsule. The combined effect, on the liverō parenchyma, of ligation of the hepatic artery and@ portal vein thrombosis, is remarkably small. $\overrightarrow{0}$ There is a slightly fatty change but no necrosis.3 The branches of the artery are contracted, and for? the most part empty. A few branches of the portalo vein contain recent thrombus.

\section{Comment}

The hepatic artery was ligated distal to the gastro-duodenal branch in this case as advocatedô by Reinhoff (1951). Berman et al. (195I) consider that the hepatic artery should be tied close음 to the coeliac axis, so as to allow of the develop- $\rightarrow$ ment of an anastomosis through the right gastric artery. They claim that one of the benefits of lowering the portal venous pressure is an improve- -9 ment of the hepatic capillary blood flow in the $N$ islands of regenerated liver cells. Thus, whilst the hepatic artery pressure is lowered by ligation nearo the coeliac axis, this developing capillary networko is supplied by the anastomosis through the right片 gastric artery and other collateral vessels.

McFadzean and Cook (1953), in a recent paper, 0 report seven cases in whom the hepatic artery waso ligated. In two of these cases the site of ligature 
was distal to the gastro-duodenal branch. They consider that this latter technique, together with splenectomy, in cases of hypersplenism is the operation of choice. They point out that massive necrosis of the liver is a possible complication of the operation, and they quote McIndoe's perfusion experiments (McIndoe, 1928). He showed that if the portal vein of a cirrhotic liver is perfused at a pressure of $20 \mathrm{~mm}$. of Mercury, then between 86 to 100 per cent. of the perfusion fluid is recovered from collateral channels, most of these being given off at pre-sinusoidal level. Therefore ligation of the hepatic artery distal to its gastroduodenal branch should, theoretically, cut off the main or possibly the entire blood supply to the liver cells. In an addendum to their paper they mention one case where this complication occurred. The case described above is of interest in that in spite of ligation of the hepatic artery distal to the gastro-duodenal branch and of portal vein thrombosis present for some few days before death, there was no necrosis of the liver parenchyma.

Splenectomy was performed on this patient and the platelet count rose from 100,000 on the day prior to operation to 377,000 by the tenth postoperative day. McFadzean and Cook have commented on the fact that hypersplenism was only corrected in those cases in which they performed splenectomy as well as hepatic artery ligation. Apart from the question of hypersplenism, removal of the spleen reduces the volume of blood returning to the portal vein, and therefore its removal should still further reduce the portal venous pressure.

In this case the operation had no effect on the rate af formation of ascites, although the rate of reaccumulation was difficult to record in the first post-operative month. The majority of reported cases, where the primary indication for operation has been intractable ascites, as it was in 13 of the 19 cases reported by McFadzean and Cook, have been followed by marked improvement. In McFadzean and Cook's series there had been no recurrence in a follow-up ranging from three months to two- anda-half years. Reinhoff and Wood (1953) in a recent paper also state that in their experience the greatest benefit of ligation of the hepatic and splenic artery was observed in those cases with intractable ascites.

Reference to the table will show that in our case the total serum proteins were normal prior to operation, but on the low side after operation. The albumin/globulin ratio was reversed both before and after operation, possibly partly due to the loss of albumin in the ascitic fluid. The serum bilirubin was raised before operation and there was a small but steady rise afterwards, the most pronounced rise being in the indirect bilirubin level. Reinhoff and Woods (1953) have commented on the occasional increase in serum bilirubin following this operation, which they suggest may be due to oedema and loss of squamous character of the bile duct epithelium.

I wish to thank Mr. F. d'Abreu and Dr. R. D. Tonkin for permission to publish this case. My thanks are also due to Professor N. F. Maclagan and his staff for the extensive biochemical investigations and to Dr. A. D. Morgan for permission to quote his reports on histological findings.

\section{BIBLIOGRAPHY}

REINHOFF, W. F., JUN. (I95I), Bull fohn. Hopk. Hosp., 88, 368. BERMAN, J. K. (195I), Arch. Surg.,.63, 623.

BERMAN, J. K., and HULL, J. E. (1952), Arch. Surg., 65, 37

MADDEN, J. L. (1953), Surg. Gynae. Obstet., 96, 594

JAHNKE, E., SEELEY, S. F., and PALMER, E. D. (1953), Ann.

Surg., 137, 98.
DESFORGES, G., CAMPBELL, A. J. A., and ROBBINS, S. L.

(1935), Ann. Surg., 137, 507.

PALMER, E. D., SBOROV, V., and JAHNKE, E. (1953), Gastroenterology, 24, 10.

BERMAN, J. K., KOENIG, H., and MULLER, L. P. (195I), Arch.'Surg., 63, 379.

MCINDOE, A. H. (1928), Arch. Path., 5, 23.
RIENHOFF, W. F., JUN., and WOODS, A. C., JUN. (1953), F.A.M.A., 152,687 .
'Spot Diagnosis. Vol. I.' Compiled by the Editors of Medicine Illustrated. Pp. 128, with 102 illustrations. London: Harvey \& Blythe, Ltd. 1954. 7s. 6d.

Ciba Foundation Symposium-The Chemical Structure of Proteins.' Edited by G. E. W. Wolstenholme, O.B.E., M.A., M.B., B.Ch. Pp. xii + 222, with 49 illustrations. London: J. \& A. Churchill, Ltd. 1953. 25s.
' Modern Treatment Yearbook 1954.' Edited by Sir Cecil Wakeley, Bt., K.B.E., C.B., L1.D., M.Ch., D.Sc., P.R.C.S., F.R.S.E., F.R.S.A., F.A.C.S., F.R.A.C.S. Pp. viii +352 , with 69 illustrations. London: Baillière, Tindall \& Cox. 1954. 2is.

'Oral and Facial Deformity.' By C. Kerr McNeil, Ph.D., L.D.S. Pp. I27, with 191 illustrations. London: Isaac Pitman \& Sons. 1954. 258. 